\title{
Biosensors, the Emerging Tools in the Identification and Detection of Cancer Markers
}

\author{
Muhammad Torequl Islam ${ }^{1,2 *}$ and Mohammad Ashab Uddin ${ }^{1}$ \\ ${ }^{1}$ Department of Pharmacy, Southern University Bangladesh, Bangladesh \\ ${ }^{2}$ Postgraduate Program in Pharmaceutical Sciences, Federal University of Piaui (UFPI), Brazil
}

Submission: March 17, 2017 ; Published: June 19, 2017

*Corresponding author: Muhammad Torequl Islam, Department of Pharmacy, Southern University Bangladesh, Bangladesh, Email: mti031124@gmail.com

\begin{abstract}
The cancer is chaos, causing impairment by biochemical pathways in a biological system. Mulfunctioning of cells throughout the human body is mostly observed in cancer and is still the outmost lethal disease in the world. There is a difference in expression of parameters within a host during its normal physiology and pathological conditions, those are identified and detected to proceed on for the treatment. A number of conventional methods are available nowadays, despite of their potential limitations. Biosensors, the analytical devices that convert biological responses into electrical signals are now popularly used in many fields such as food industry, metabolic engineering, plant biology, marine science, defense, drug discovery and development. Beside these, in the medical sectors, their important roles are remarkable, especially in the early detection of a disease, and monitoring the therapeutic progression and disease state. To date, diagnostic tests by using biosensors for the early detection of cancer biomarkers are available; these provide noninvasive/minimally invasive assays with high through output and patient survival rate. This paper reviews an overview on biosensor-implementation in some cancers along with their future applicability.
\end{abstract}

Keywords: Biomarker; Biosensor; Cancer; Diagnosis

Abbreviations: 18F-FDG: 18F-Fluorodeoxyglucose; AFP: Alpha-Fetoprotein; AKT: Protein Kinase B; AMARC: Methylacyl Alpha CoA Racemase; AuNPs: Gold Nanoparticles; B2M: Beta-2-Microglobulin; BRAF: B-Raf; BRCA: Breast Cancer Associated Gene; CA: Cancer Antigen; CAPB: Cocamidopropyl Betaine; CD: Cytotoxic T Cell; CEA: Carcinoembryonic Antigen; CGH: Comparative Genomic Hybridization; CK: Creatine Kinase; CRP: C-Reactive Protein; CTC: Cutaneous T Cell; CYFRA: Cytokeratin Fragment; DD3: Discoidin Domain 3; DDR2: Discoidin Domain Receptor 2; DCIS: Ductal Carcinoma In Situ; DEPDC1: N,N-Diethyl-1,4-Phenylene Domain Containing 1; Dsdna: Double-Stranded DNA; EGFR: Epidermal Growth Factor Receptor; ELAC2: Elac Ribonuclease Z 2; ELF: Epithelial Lining Fluid; ELISA: Enzyme-Linked Immunosorbent Assay; EPCA: Early Prostate Carcinoma Antigen; Epcam: Epithelial Cell Adhesion Molecule; ER: Estrogen Receptor; EX01: Exonuclease 1; FISH: Fluorescence In Situ Hybridization; FOXM1: Forkhead Box Protein M1; HAPLN1: Hyaluronan And Proteoglycan Link Protein 1; HE4: Human Epididymis Secretory Protein 4; HER2: Human Estrogen Receptor 2; $\mathrm{HfO}_{2}$ : Hafnium Oxide; HPC: Haematopoietic Progenitor Cell; HPC1: Haematopoietic Progenitor Cell 1; HPCX: Haematopoietic Progenitor Cell X; HPV: Human Papillomavirus; IHC: Immunohistochemistry; IL: Interleukin; IUPAC: International Union of Pure and Applied Chemistry; KEAP1: Kelch-Like ECH-Associated Protein 1; KRAS: K-Ras; LDCT: Low-Dose Computed Tomography; M-CSF: Macrophage Colony-Stimulating Factor; Mirna: Micro Ribonucleic Acid; MRI: Magnetic Resonance Imaging; MUC1: Mucin 1; NCI: National Cancer Institute; NFE2L2: Nuclear Factor, Erythroid 2 Like 2; NUSAP1: Nucleolar And Spindle Associated Protein 1; P53: Protein 53; PCAP: Pulmonary Capillary Pressure; PET: Positron Emission Tomography; PIK3CA: Phosphoinositide 3-Kinase Catalytic Subunit Alpha; PNA: Peptide Nucleic Acid; PR2: Progesterone Receptor 2; PSA: Prostate-Specific Antigen; PTEN: Phosphatase and Tensin Homolog; QCM: Quartz Crystal Microbalance; QDs: Quantum Dots; Qpcr: Quantitative Polymerase Chain Reaction; RT-PCR: Real-Time Polymerase Chain Reaction; Real-Time qrt-PCR: Real-Time Quantitative Reverse Transcription PCR; RRM2: RNA Recognition Motif 2; SPP1: Secreted Phosphoprotein 1; SPR: Surface Plasmon Resonance; Ssdna: Single-Stranded DNA; TATI: Tumour-Associated Trypsin Inhibitor; TNF: Tumor Necrosis Factor; TPA: Tissue Plasminogen Activator; TPS: Thermoplastic System

\section{Introduction}

Evidences suggest that an increasing number of attentions have been focused on developing rapid techniques called 'biosensor technology' for the identification, detection and monitoring of human health-related conditions. The biosensors are the bioanalytical devices, incorporating molecular recognition together with physicochemical transducers, for the analysis of biomarkers. The term "biosensor" was first used by Cammann [1] and its definition was introduced by the 
International Union of Pure and Applied Chemistry (IUPAC) [2]; finally started the journey in the 1960 s by the pioneers Clark and Lyons. A biosensor connects chemistry, biology, and engineering in its fabrication. Based on the mechanism, the materials used in biosensors are: biocatalytic group comprising enzymes, bio affinity group, including antibodies, antigens and nucleic acids, and microbe-based containing microorganisms. Till date, different types of biosensors are: enzyme-based; microbe-based or cell-based; tissue-based; immunosensors; protein, DNA or genetically-encoded biosensors; electrochemical, magnetic, optical, thermal and piezoelectric biosensors. Each biosensor has a conformation and uniqueness in its fabrication and application. A common illustration of the function of biosensor has been shown in Figure 1.

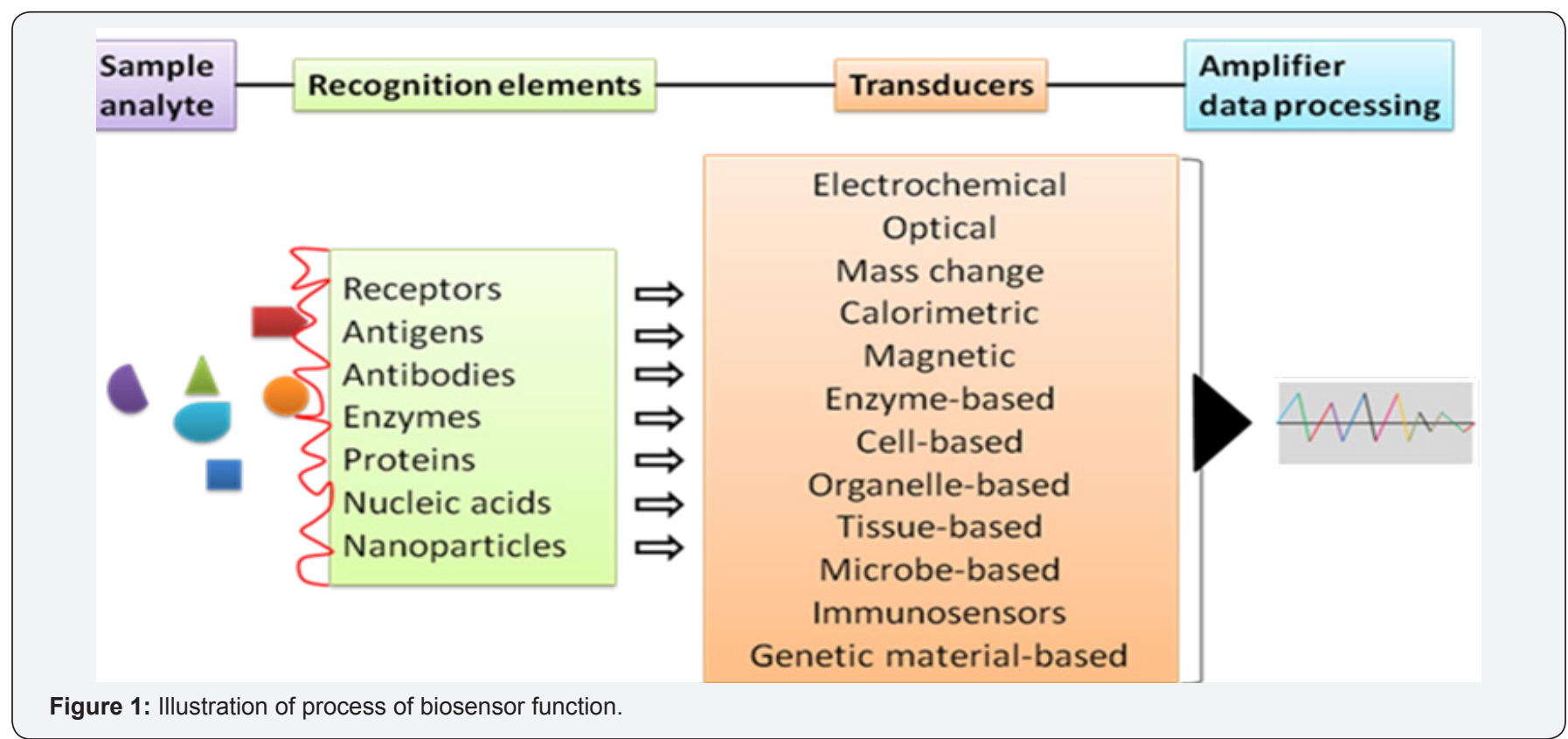

The applications of biosensors are growing day by day. Till date, they can be found in- food and fermentation industry, plant biology, in defense, marine science, drug discovery and medical sciences.

In the diagnostic centers, glucose biosensors are widely used for the detection of blood-glucose levels [3]. Biosensor, based on hafnium oxide $\left(\mathrm{HfO}_{2}\right)$, is used for the detection of human interleukin (IL)-10 [4] in cardiovascular patients. Biosensors are also engaged in the diagnosis of infectious diseases and anti-microbial susceptibility. Other important applications of biosensors include: quantitative measurement of cardiac markers in undiluted serum, microfluidic impedance assay for controlling endothelin-induced cardiac hypertrophy, immunosensor array for clinical immunophenotyping of acute leukemias, effect of oxazaborolidines on immobilized fructosyltransferase in dental diseases; histone deacylase (HDAC) inhibitor assay from resonance energy transfer, biochip for a quick and accurate detection of multiple cancer markers and neurochemical detection by diamond microneedle electrodes.

According to the National Cancer Institute (NCI), United States 2015 report approximately 1,658,370 new cases of cancer have been diagnosed and 589,430 deaths. The literature says that, in human the most common cancers are: breast, lung, bronchus, prostate, colon, rectum, skin melanoma, Hodgkin lymphoma, thyroid, liver, renal pelvis, endometrial, leukemia and pancreatic cancer [5]. It is doubtless that, the cancer is a multifactorial molecular disease that includes multistage development of tumor cells, caused by a range of genetic or environmental factors, such as exposure to carcinogenic chemicals or radiation, or has a microbiological cause, including bacterial (e.g. - stomach cancer) or viral (e.g. - cervical cancer) infection. In this context, promoter proliferative signaling, escapes from growth suppressors, resistive cell death, replicative immortality, triggering of angiogenesis, and activation of invasion and metastasis are occurring along with the genomic instability, inflammation, and epigenetic changes. Thus, determination of responsible genes, proteins, and abnormalities in the tumor and body fluids such as blood, urine and sputum in the early stage is crucial for an effective treatment.

Microarrays, quantitative polymerase chain reaction (qPCR) and enzyme-linked immunosorbent assay (ELISA) are the frequently used detection methods in cancers. The common disadvantages of these techniques are: expensive, requires highly qualified personnel, time consuming, laboratory-dependent, difficulty in handling, tissue oxidation (qPCR), limited access, destructive testing (microarrays), lack of flexibility in selecting standards, quality and sampling amount [6]. Although, biosensors have limited use in clinics and the molecular markers are not reproducible, but they can overcome other limitations as said above. Moreover, the in situ application, high analytical specificity, cost-effectiveness in time and material consumption, 
sensitivity through automation, integration of multiple processes in a single device, low-space occupancy and multi-analyte testing capability are the major causes of increasing popularity of biosensors $[7,8]$.

This text focuses a brief scenario on biosensors involvement and applicability in the monitor and detection of early cancer development. Additionally, the hopes and challenges are also plugged in.

\section{Designing of biosensors for early cancer detection}

To monoclonal antibodies and aptamers (oligonucleotide or peptide molecules that bind to a specific target molecule) are often used to capture cancer agents, including antigens, while micro ribonucleic acids (miRNAs) corresponds single stranded desoxyribonucleic acid (ssDNA). The transducer, in a biosensor converts the molecular recognition signal to an electrical signal. It may be electrochemical (potentiometry, amperometry, conductometry/impedimetry), optical (fluorescence, luminescence, colorimetric and interferometry), calorimetric (thermistor) or based on mass changes (piezoelectric/ acoustic waves) [9] (Figure 1).

The electrochemical biosensors detect an electrical response when there is a molecular recognition of a specific element. For an example- detection of cancer marker hPRL-3 in breast cancer cells [10]. By utilizing specific DNA sequences, it is possible to recognize elements in cancer and/or conjoined with genetic mutations. BRCA1 and BRCA2 mutations are associated with hereditary breast cancer. This type of biosensor has the ability to detect damaged DNA and carcinogens associated with the damage [11]. Moreover, by using multiple sensors with multiple transducers, it is also possible to detect multiple factors associated with a particular cancer. The cytosensors are the electrochemical-cell-based biosensors utilize living cells as a biological recognition element [12].

Optical biosensors measure the changes in specific wavelengths of light [13]. The biosensors with photonic crystals can capture the light areas or very small volumes and transmit the light to a high electromagnetic field to display the result. These types of biosensors are implemented for monitoring changes in proliferation and apoptosis of breast cancer cells, the rate of drug cytotoxicity and understanding the effectiveness of the treatment. Optical biosensor based on laser-induced fluorescence is evident to use in the diagnosis and monitoring of throat cancer. Interestingly, the use of this biosensor prevented surgical biopsies and the pain associated recovery in more than 200 patients [11].

The mass change biosensors e. g. -piezoelectric biosensors measure the changes in resonance frequency of a piezoelectric crystal in the manner of changing mass on the crystal structure. By using these biosensors coupled with polymerase chain reaction (PCR) amplifications, it is possible to detect the point of mutations in the human p53 gene.
The use of calorimetric biosensors is rarely in the diagnosis of cancer. They measure exothermic reactions. However, in a study with gold nanoparticles (AuNPs), calorimetric biosensors successfully detected two different types of cells in acute leukemia and cells in Burkitt's. Wang et al. [14] suggested that 2D nanomaterial-based biosensors can be used to detect cancer biomarkers. These, mainly cover the graphene, grapheme derivatives (i.e. -grapheme oxide and reduced grapheme oxide), and graphene-like nanomaterials (i.e. -2D layered transition metal dichalcogenides, graphite carbon nitride and boron nitride nanomaterials).

The enzyme-based biosensors have been devised on immobilization methods, i.e. adsorption of enzymes by chemical bonding such as Van der Waals forces, ionic or covalent bonding. The commonly used enzymes for this purpose are oxidoreductases, polyphenol oxidases, peroxidases, and aminooxidases [15]. The analyte of the tissue-based biosensors are the inhibitors or substrates, including amino acids. On the other hand, the organelle-based biosensors are used to detect the membranes, chloroplasts, mitochondria, and microsomes. Immunosensors act through an interaction between antibodies with their specific antigens. In this case, the antibodies specifically bind to pathogens or toxins, or interact with components of the host's immune system. The microbe-based biosensors detect the microorganisms (both live and dead) or their liberated materials, while DNA biosensors are devised on the property that single-strand nucleic acid molecule is able to recognize and bind to its complementary strand in a sample. In the latter case, an interaction occurs by the formation of stable hydrogen bonds between the two nucleic acid strands [16]. The magnetic (miniaturized) biosensors detect magnetic micro- and nanoparticles in microfluidic channels using the magnetoresistance effect [17]. These can be also applied for the detection of microorganisms.

\section{Biosensor-detectable biomarkers in some cancers}

Malignant cells produce biological substances, including pro-inflammatory and inflammatory mediators. Moreover, a number of intra- and intercellular compounds, such as hormones, mucin, isoenzymes, oncogenes, oncofetal antigens, tissue-specific proteins, circulating ribonucleic acids, and some glycoproteins and glycolipids are also the indicators of cancer $[18,19]$. Some of these markers are organ specific, while others are common. For example, neuron-specific enolase and a breast cancer gene are specific for lung and breast car $\urcorner$ cinomas, respectively; whereas cancer antigen 15-3, cancer antigen 125 and carcinoembryonic antigen may be found in breast, lung, or colon cancer. More complications are seen in the expression of miRNAs in some diseases. Otherwise, biomarkers can show different concentration level in different type of cancer [20]. The hysiology, gender and racial factors also have an influence on the levels of a certain or group of biomarkers. Techniques used for biomarkers identification and detection are shown in Box 1. 


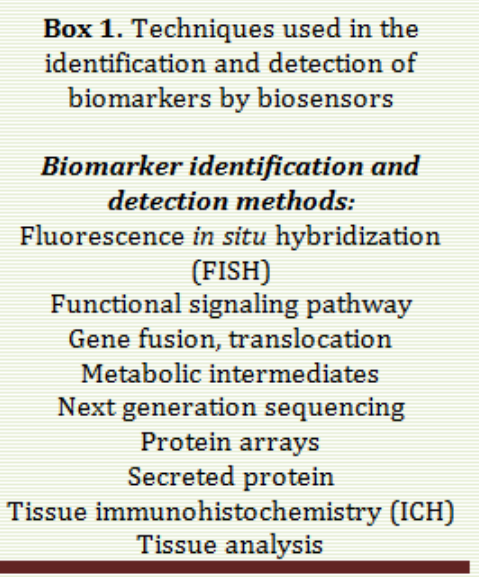

Box 1: Techniques used in the identification and detection of biomarkers by biosensors.

Gene biomarkers have more specificity in cancers due to the genome diversity. A number of genes have been linked to somatic mutations in human tumor cells or tissues, including oncogenes and tumor suppressor genes, as well as genes encoding proteins that perform key functions in regulation of the cell cycle, DNA repair, and enzyme activity. For example, protein 53 (p53) gene, which is located on the short arm of the chromosome 17 in the human genome and is thought as a guardian of the genome, as it regulates the cell cycle and functions as a tumor suppressor [21]. However, a single mutation in the same location can initiate different cancers depending on the geographical location, ethnic back $\urcorner$ ground, and/or gender of the patient. For an example, p53 proline mutation has been found to link in pancreatic cancer in males [22], which has been found to decrease the risk of breast cancer in Arab women [23].

The location of the mutation is also related to the situations of a particular cancer, such as codon 273 mutation in non-small cell lung cancer, while codon 248 for small cell lung cancer in the p53 gene [24]. The other detectable target may be the epidermal growth factor receptor (EGFR), responsible for tumor invasion, angiogenesis, cell proliferation, and apoptosis [25].

Table 1: Biosensor techniques applied for the detection of cancer biomarkers.

\begin{tabular}{|c|c|c|c|c|}
\hline Biomarker & Biosensor & Surface Ligand & Detection Limit & Reference \\
\hline \multirow{3}{*}{ AFP } & \multirow{3}{*}{ Electrochemical* } & Microfluidic immunosensor & 1 to $10103 \mathrm{ng} / \mathrm{mL}$ & Maeng et al. [30] \\
\hline & & $\begin{array}{l}\text { Graphene and thionin nanocomposit } \\
\text { film }\end{array}$ & $5.66 \mathrm{pg}$ to $2 \mathrm{ng} / \mathrm{mL}$ & Wei et al. [60] \\
\hline & & Antibody & $50 \mathrm{pg}$ to $500 \mathrm{ng} / \mathrm{mL}$ & Tang et al. [57] \\
\hline CAI5-3 & Electrochemical* & Antibody & $10 \mathrm{U} / \mathrm{mL}$ & Altintas et al. [61] \\
\hline CA19-9 & SPR\# & Antibody & $66.7 \mathrm{U} / \mathrm{mL}$ & Chung et al. [62] \\
\hline \multirow{3}{*}{ CEA } & Electrochemical* & Antibody & $0.1 \mathrm{pg}$ to $500 \mathrm{ng} / \mathrm{mL}$ & Altintas et al. [63] \\
\hline & $\mathrm{SPR}^{*}$ & \multirow{2}{*}{ Antibody } & \multirow{2}{*}{ Up to $3 \mathrm{ng} / \mathrm{mL}$} & \multirow{2}{*}{ Ladd et al. [64] } \\
\hline & SPR\# & & & \\
\hline \multirow{2}{*}{ CRP and TNF } & \multirow{2}{*}{ Electrochemical* } & \multirow{2}{*}{ Antibody } & 3.2 to $10.4 \mu \mathrm{g} / \mathrm{mL}$ & Lee et al. [65] \\
\hline & & & $25 \mathrm{pg}$ to $25 \mathrm{ng} / \mathrm{mL}$ & Qureshi et al. [66] \\
\hline \multirow{2}{*}{ CRP } & \multirow{2}{*}{$\mathrm{QCM}^{*}$} & \multirow{2}{*}{ Antibody } & $0.1 \mathrm{pM}$ to $0.53 \mathrm{nM}$ & Kim et al. [67] \\
\hline & & & $0.3 \mathrm{ng}$ to $0.5 \mathrm{mg} / \mathrm{mL}$ & Kim et al. [59] \\
\hline DNA mutations & $\mathrm{SPR}^{*}$ & ssDNA & $50 \mathrm{nM}$ & Ladd et al. [64] \\
\hline \multirow{2}{*}{ EGFR } & Optical* & Aptamer & \multirow{2}{*}{ - } & Ilyas et al. [68] \\
\hline & Lab-on-a-chip* & Antibody & & Kallempudi et al. [69] \\
\hline $\begin{array}{l}\text { K-ras point } \\
\text { mutation }\end{array}$ & SPR\# & PNA & - & Sato et al. [71] \\
\hline \multirow{4}{*}{ PSA } & \multirow{3}{*}{ Electrochemical* } & Antibody & $1 \mathrm{pg}$ to $35 \mathrm{ng} / \mathrm{mL}$ & Triroj et al. [77] \\
\hline & & Nanoparticle-antibody & $5 \mathrm{pg}$ to $10 \mathrm{ng} / \mathrm{mL}$ & Wei et al. [78] \\
\hline & & Nanoparticle-antibody & 0.005 to $50 \mathrm{ng} / \mathrm{mL}$ & Li et al. [79] \\
\hline & SPR* $^{*}$ & Antibody & $0.02-2.3 \mathrm{ng} / \mathrm{mL}$ & Lin et al. [79] \\
\hline$p 53$ gene & SPR\# & Antibody and dsDNA & 1.06 and $10.6 \mathrm{pM}$ & Wang et al. [14] \\
\hline p53 point mutation & SPR\# and QCM\# & ssDNA & $0.03 \mu \mathrm{M}$ & Altintas [39] \\
\hline \multicolumn{5}{|c|}{$\begin{array}{c}\text { *Serum; \#Non-Mentioned; AFP: Alpha-Fetoprotein; CA: Cancer Antigen; CEA: Carcinoembryonic Antigen; CRP: C-Reactive } \\
\text { Protein; dsDNA: Double-Stranded DNA; EGFR: Epidermal Growth Factor Receptor; PNA: Peptide Nucleic Acid; PSA: Prostate- } \\
\text { Specific Antigen; SPR: Surface Plasmon Resonance; ssDNA: Single-Stranded DNA; TNF: Tumor Necrosis Factor; QCM: Quartz } \\
\text { Crystal Microbalance. }\end{array}$} \\
\hline
\end{tabular}


Genomic and proteomic analyses are performed to determine potential biomarkers, since the combined data are much more reliable and precise than the data obtained using a single methodology and helpful to find out more specific gene or protein biomarkers for a particular cancer type [26,27]. In protein chip biomarkers, the proteins are isolated and printed on a single slide surface can investigate protein profiling and antibodies via protein-protein interactions [28]. On the other hand, post-genomic technologies and bioinformatics tools are helpful to detect gene expression, mutations, single nucleotide polymorphisms, and cancer biology [29]. Till date, a number of biosensors have been introduced to detect cancer (some of them are shown in Table 1. An electrochemical molecular beacon biosensor has been developed for the sequence-specific recognition of DNA for cancer diagnosis and gene therapy, while the molecular beacon-based biosensors can be used to detect protein biomarkers, small molecules, and RNA. Double stranded DNA biosensors are capable to quantify within the range of $350 \mathrm{pM}$ to $25 \mathrm{nM}$ [30]. Potentiometric biosensors combining the effect and specific molecular imprinting can be used to detect cancer, carcinoembryonic antigen, discriminate between damaged and normal fibrinogen in bleeding disorders, and conformational changes in the protein [31]. Hyaluronan and proteoglycan link protein 1 (HAPLN1) can be used by using an electrochemical open-circuit potential method [32]. On the other hand, piezoelectric biosensor was developed to detect the prostate-specific antigen (PSA) and alpha-fetoprotein (AFP). A titanate zirconate ceramic resonator could success $\neg$ fully detect PSA and AFP up to $0.25 \mathrm{ng} / \mathrm{mL}$ in a short time (30 minutes) with a small sample volume (1 $\mu \mathrm{L})$ [33].

Nanoparticles have a wide range of applications for detection of different types of disease, such as cancer, infec $\neg$ tious diseases, and neurological disorders [34]. Short fragments of DNA can be tagged with AuNPs for the detection of targeted gene sequences. On the other hand, quantum dots (QDs) and magnetic iron oxide nanoparticles can be designed for dual-mode imaging of cancer. The silica and iron oxide nanoparticles can be used to detect lung cancer cells [35]. AuNPs-conjugated anti-EGFR antibodies are evident to show $600 \%$ higher binding affinity with cancerous cells than noncancerous cells [36]. Manganese oxide nanoparticles combined with magnetic resonance imaging (MRI) can be used to diagnose neurological disorders such as Parkinson's disease, stroke, and Alzheimer's disease [37]. Moreover, there is a chance to attach the affinity ligands such as antibodies to these nanoparticles. The later type of fabrication can detect bacteria, while silver nanorods have been introduced for a rapid quantification and characterization of viruses, by recognizing spectral differences between viral strains, viruses, and viruses with gene deletions in biological samples [38]. The multicolor optical coding using QDs is also another important application in molecular diagnosis [39]. On the other hand, bio conjugated QDs are useful to detect disease progression, and response to therapy [40].
The ovarian cancer exhibits a wide range morphologies and variations in clinical and genetic ways during the process of tumor progression. In this cancer, the beta-2-microglobulin (B2M) is found to over express, that can be a useful tool to detect [41]. However, targeting of a single molecular marker is not enough [42]. In breast cancer, the detection of hormone receptors, such as estrogen (ER), progesterone receptor 2 (PR2) and the EGFR is commonly done. Although, the immune histochemistry (IHC) is used as a quantitative method to detect the expression of HER2 receptors, but is has some disadvantages in fixing protocols, registration systems and level of placement, and the selection of antibodies [43]. On the other hand, in cervical cancer the expression of the E6, E7 and E5 of the high-risk subtypes of human papillomavirus (HPV) oncoproteins can be measured in cervical cancer. Although, it requires long periods of latency for the malignant transformation [44], but can be detected using a novel leaky surface acoustic wave peptide nucleic acid biosensor with double two-port resonators.

The linear discriminatory analysis, microarrays and RealTime Quantitative Reverse Transcription PCR (Real-Time qRT-PCR) have been used for the diagnosis of prostate cancer with 100\% accuracy [45]. The AMARC (methylacyl alpha CoA racemase), an enzyme involved in the oxidation of branched chain fatty acids, which is evident to overexpress in prostate and some other cancers. In this regard, IHC antigen P504S is helpful to detect AMACR. Additionally, the blood and urine samples are also useful to detect the gene mRNA of AMACR using qRTPCR, while the nuclear matrix protein, early prostate carcinoma antigen (EPCA) by using ELISA or tissue IHC [46].

In lung cancer, low-dose computed tomography (LDCT) is widely used [47]. A combination of computed tomography and positron emission tomography with 18F-fluorodeoxyglucose (18F-FDG PET/CT) is also used in this case. Generally, the growth of a tumor is accompanied by changes in genes and proteins. Thus the point of methylation or mutations of DNA, RNA and protein expression can be targeted. Some other biomarkers can also be helpful in this purpose, such as altered carbohydrates, cytokines and chemokines, volatile organic compounds from the peroxidation in the cell membrane [48]. In lung cancer, the other mutations can be detected as: BRAF [49], KRAS [50-52], HER2 [53,54], DDR2, PIK3CA, PTEN, AKT, KEAP1, and NFE2L2 [55]. Furthermore, recurrent gene rearrangements involve: ALK, ROS1, RET and NTRK in this cancer $[56,57]$.

The AFP is a normal serum protein synthesized by liver, yolk sac and gastrointestinal tract. Over expression of AFP, is evident to cause liver cancer [58]. On the other hand, C-reactive protein (CRP), synthesized by IL- 6 in the liver, circulates in the blood is a prognostic indicator of gastric cancer [59-65]. These types of biomarkers can be detected in serum by using electrochemical and quartz crystal microbalance (QCM) techniques. In breast cancer the detectable biomarkers are: ER, PR, HER2, BRCA1, Ki67, osteopontin, mammoglobin, sirtuins, autoantibodies, 
CA15-3, CA27.29, CTC, CEA, BRCA1, BRCA2, MUC1, EpCAM, biomarkers in some cancers has been shown along with the EGFR, miR-21, 16, 27a, 150, 155, 191, 222. In Table 2, a list of molecular detection methods [66-76].

Table 2: Biomarkers in some cancers and currently available molecular detection methods

\begin{tabular}{|c|c|c|c|}
\hline Cancers & Biomarkers & Molecular Detection Methods & References \\
\hline Lung & $\begin{array}{c}\text { (Tenascin-C, [C-X-C motif] ligand } 14, \text { S100 calcium binding } \\
\text { protein A9, and keratin 17) in upregulated ELF, CD24+/ } \\
\text { CD38- }\end{array}$ & $\begin{array}{l}\text { Microarray, qRT-PCR, flow } \\
\text { cytometry }\end{array}$ & Karimi-Busheri et al. [87] \\
\hline Breast & $\begin{array}{l}\text { Up-regulation of DCIS: DEPDC1, NUSAP1, EX01, RRM2, } \\
\text { FOXM1, MUC1 and SPP1, other markers: anti-CK7, anti- } \\
\text { CK20, anti-pan-CK, anti-CK8/CK18, anti-CK8, and anti- } \\
\text { CK18, Ki-67, hormone receptors, and EGFR2 }\end{array}$ & $\begin{array}{l}\text { RT-PCR, microarray, gene } \\
\text { expression, flow cytometer }\end{array}$ & Cruz et al. [87] \\
\hline Prostate & $\begin{array}{l}\text { DD3, PSA, HPC1, CAPB, PCAP, ELAC2, HPC20, 8p 22-23, } \\
\text { HPCX }\end{array}$ & $\begin{array}{l}\text { FISH, CGH, qRT-PCR, gene } \\
\text { expression, flow cytometry }\end{array}$ & Miller et al. [90] \\
\hline Ovary & $\begin{array}{l}\text { CA125, HE4, mesothelin, M-CSF, osteopontin, kallikrein(s) } \\
\text { and soluble EGFR, (CA 125, CA 19.9, TATI, CASA, CEA, TPA, } \\
\text { TPS and CYFRA21-1) }\end{array}$ & $\begin{array}{l}\text { RT-PCR, microarray, gene } \\
\text { expression, flow cytometry }\end{array}$ & Bast et al. [92] \\
\hline Uterine cervix & Over-expression G30CC, erbB2 (HER2/neu) & RT-PCR, flow cytometry & Cheng et al. [62] \\
\hline \multicolumn{4}{|c|}{$\begin{array}{l}\text { CA: Cancer Antigen; CAPB: Cocamidopropyl Betaine; CD: Cytotoxic T Cell; CEA: Carcinoembryonic Antigen; CGH: Comparative Genomic } \\
\text { Iybridization; CK: Creatine Kinase; CYFRA: Cytokeratin Fragment; DD3: Discoidin Domain 3;; DCIS: Ductal Carcinoma In Situ; DEPDC1: N,N- } \\
\text { iethyl-1,4-Phenylene Domain Containing 1; EGFR: Epidermal Growth Factor Receptor; ELAC2: Elac Ribonuclease Z 2; ELF: Epithelial Lining } \\
\text { luid; EX01: Exonuclease 1; FISH: Fluorescence In Situ Hybridization; FOXM1: Forkhead Box Protein M1; HE4: Human Epididymis Secretory } \\
\text { Protein 4; HER2: Human Estrogen Receptor 2; HPC: Haematopoietic Progenitor Cell; HPCX: Haematopoietic Progenitor Cell X; M-CSF: } \\
\text { acrophage Colony-Stimulating Factor; MUC1: Mucin 1; NUSAP1: Nucleolar And Spindle Associated Protein 1; RT-PCR: Real-Time Polymerase } \\
\text { Chain Reaction; Real-Time Qrt-PCR: Real-Time Quantitative Reverse Transcription PCR; RRM2: RNA Recognition Motif 2; SPP1: Secreted } \\
\text { Phosphoprotein 1; TATI: Tumour-Associated Trypsin Inhibitor; TPA: Tissue Plasminogen Activator; TPS: Thermoplastic System. }\end{array}$} \\
\hline
\end{tabular}

\section{Concluding remarks}

With the biosensor and molecular techniques, it can be said that a number of molecular markers available may be excellent candidates for the identification and detection by using biosensors. Moreover, the use of biosensors in the early detection of cancer and monitoring the overall progress of disease state is the hopeful keys for the effective treatment, thus reducing the mortality rate of the patients [77-80]. Biosensors can be used in some laboratory tasks, including genotoxic and mutagenic markers such as chromosomal aberrations and micronucleus tests [81-85].

Doubtless, before treatment- proper diagnosis is essential. In this sense, still there is a long way to go to understand a complete set of markers in a particular cancer. Non-specificity in expression of some markers may offer wrong diagnosis, therefore, wrong treatment [86-90]. Otherwise, the problems in the reproducibility of the method and difficulties in the fabrication of the biosensor materials are also should be resolved. The level of detection is another fact in this novel technology, as the expression of biomarkers depends on: duration of disease, patient's pathophysiology, age, gender, genetic diversity, the conditions for taking of tissue, lifestyle of the patient, earlier and concurrent treatment received and so on.

However, continuity in research may be helpful to overcome the overall challenges those are yet to be resolved with the application of the biosensor in cancers. Finally, it is doubtless that, the biosensor technology has opened a hopeful door in the diagnosis, therefore earlier treatment- thus the possibility of an increase in the survival rate or lifespan, by decreasing suffering and mortality rate of the cancer patients [91-95].

\section{References}

1. Cammann K (1977) Biosensors based on ion-selective electrodes. Fresen Z Anal Chem 287: 1-9.

2. Thevenot DR, Toth K, Durst RA, Wilson GS (2001) Electrochemical biosensors: recommended definitions and classification. Biosens Bioelectron 16(1-2): 121-131.

3. Scognamiglio V, Pezzotti G, Pezzotti I, Cano J, Buonasera K, et al. (2010) Biosensors for effective environmental and agrifood protection and commercialization: from research to market. Mikrochim Acta 170(3): 215-225.

4. Lee M, Zine N, Baraket A, Zabala M, Campabadal C, et al. (2012) A novel biosensor based on hafnium oxide: application for early stage detection of human interleukin-10. Sens Actuators B 175: 201-207.

5. NIC (National Institute of Cancer) (2015) What is Cancer?

6. Altintas Z, Uludag Y, Gurbuz Y, Tothill IE (2011) Surface plasmon resonance based immunosensor for the detection of the cancer biomarker carcinoembryonic antigen. Talanta 86: 377-383.

7. Chung CC, Ciampa J, Yeager M, Jacobs KB, Berndt SI, et al. (2011) Fine mapping of a region of chromosome $11 \mathrm{q} 13$ reveals multiple independent loci associated with risk of prostate cancer. Hum Mol Genet 20(14): 2869-2878.

8. Tang W, Fu YP, Figueroa JD, Malats N, Garcia-Closas M, et al. (2012) Mapping of the UGT1A locus identifies an uncommon coding variant that affects mRNA expression and protects from bladder cancer. Hum Mol Genet 21(8): 1918-1930.

9. Zhang Y, Yang D, Weng L, Wang L (2013) Early lung cancer diagnosis by biosensors. Int J Mol Sci 14(8): 15479-15509.

10. Jia Y, Qin M, Zhang H, Niu W, Li X, et al. (2007) Label-free biosensor: a 
novel phage-modified Light Addressable Potentiometric Sensor system for cancer cell monitoring. Biosens Bioelectron 22(12): 3261-3266.

11. Bohunicky B, Mousa SA (2010) Biosensors: the new wave in cancer diagnosis. Nanotechnol Sci Appl 4: 1-10.

12. Asphahani F, Zhang M (2007) Cellular impedance biosensors for drug screening and toxin detection. Analyst 132(9): 835-841.

13. Tothill IE (2009) Biosensors for cancer markers diagnosis. Semin Cell Dev Biol 20(1): 55-62.

14. Wang L, Xiong Q Xiao F, Duan H (2017) 2D nanomaterials based electrochemical biosensors for cancer diagnosis. Biosens Bioelectron 89(Pt 1): 136-151.

15. Akyilmaz E, Yorganci E, Asav E (2010) Do copper ions activate tyrosinase enzyme? A biosensor model for the solution. Bioelectrochem 78(2): 155-160

16. Wang J (1998) DNA biosensors based on peptide nucleic acid (PNA) recognition layers. A review. Biosens Bioelectron 13(7-8): 757-762.

17. Scognamiglio V, Arduini F, Palleschi G, Rea G (2014) Biosensing technology for sustainable food safety. Trends Anal Chem 62: 1-10.

18. Fakanya WM, Altintas Z, Tothill IE (2013) Biosensors for heart disease diagnosis. In: Biosensors and their application in healthcare. Future Science Group, UK, pp. 128-143.

19. Altintas Z, Kallempudi SS, Gurbuz Y (2014) Gold nanoparticle modified capacitive sensor platform for multiple marker detection. Talanta 118: 270-276.

20. Islam MT, Riaz TA, Ferdous J, Rahman A, Guha B, et al. (2016) Dictatorial streaming of biomarkers in some diseases. Int J Appl Pharm Sci Res 1: 104-118.

21. Isobe M, Emanuel BS, Givol D, Oren M, Croce CM (1986) Localization of gene for human p53 tumour antigen to band 17p13. Nature 320(6057): 84-85.

22. Sonoyama T, Sakai A, Mita Y, Yasuda Y, Kawamoto H, et al. (2011) TP53 codon 72 polymorphism is associated with pancreatic cancer risk in males, smokers and drinkers. Mol Med Rep 4(3): 489-495.

23. Alawadi S, Ghabreau L, Alsaleh M, Abdulaziz Z, Rafeek M, et al. (2011) P53 gene polymorphisms and breast cancer risk in Arab women. Med Oncol 28(3): 709-715.

24. Hainaut P, Pfeifer GP (2001) Patterns of p53 G $\rightarrow$ T transversions in lung cancers reflect the primary mutagenic signature of DNA-damage by tobacco smoke. Carcinogen 22(3): 367-374.

25. Ciardiello F, Tortora G (2008) EGFR antagonists in cancer treatment. New Engl J Med 358(11): 1160-1174.

26. Ørntoft TF, Thykjaer T, Waldman FM, Wolf H, Celis JE (2002) Genomewide study of gene copy numbers, transcripts, and protein levels in pairs of non-invasive and invasive human transitional cell carcinomas. Mol Cell Proteomics 1(1): 37-45.

27. Kanehisa M, Bork P (2003) Bioinformatics in the post-sequence era Nat Genet 33: 305-310.

28. Pauly F, Smedby KE, Jerkeman M (2014) Identification of B-cell lymphoma subsets by plasma protein profiling using recombinant antibody microarrays. Leuk Res 38: 682-690.

29. Frangogiannis NG (2012) Biomarkers: hopes and challenges in the path from discovery to clinical practice. Transl Res 159(4): 197-204.

30. Maeng JH, Lee BC, Ko YJ, Cho W, Ahn Y, et al. (2008) A novel microfluidic biosensor based on an electrical detection system for alphafetoprotein. Biosens Bioelectron 23(9): 1319-1325.

31. Zelada-Guillén GA, Tweed-Kent A, Niemann M, Göringer HU, Riu J, et al. (2013) Ultrasensitive and real-time detection of proteins in blood using a potentiometric carbon-nanotube aptasensor. Biosens Bioelectron 41: 366-371.

32. Mathur A, Blais S, Goparaju CM, Neubert T, Pass H, et al. (2013) Development of a biosensor for detection of pleural mesothelioma cancer biomarker using surface imprinting. PLoS One 8(3): 1-8.

33. Su L, Zou L, Fong CC, Wong WL, Wei F, et al. (2013) Detection of cancer biomarkers by piezoelectric biosensor using PZT ceramic resonator as the transducer. Biosens Bioelectron 46: 155-161.

34. Jain KK (2007) Applications of nanobiotechnology in clinical diagnostics. Clin Chem 53(11): 2002-2009.

35. Choi JS, Jun YW, Yeon SI, Kim HC, Shin JS, et al. (2006) Biocompatible heterostructured nanoparticles for multimodal biological detection. J Am Chem Soc 128(50): 15982-15983.

36. El-Sayed IH, Huang X, El-Sayed MA (2005) Surface plasmon resonance scattering and absorption of anti-EGFR antibody conjugated gold nanoparticles in cancer diagnostics: applications in oral cancer. Nano Lett 5(5): 829-834.

37. Na HB, Lee JH, An K, Park YI, Park M, et al. (2007) Development of a T1 contrast agent for magnetic resonance imaging using $\mathrm{MnO}$ nanoparticles. Angew Chem Int Ed Engl 46(28): 5397-5401.

38. Shanmukh S, Jones L, Driskell J, Zhao Y, Dluhy R, et al. (2006) Rapid and sensitive detection of respiratory virus molecular signatures using a silver nanorod array SERS substrate. Nano Lett 6(11): 2630-2636.

39. Altintas Z, Tothill I (2013) Biomarkers and biosensors for the early diagnosis of lung cancer. Sens Actuators B Chem 188: 988-998.

40. Xing Y, Chaudry Q, Shen C, Kong KY, Zhau HE, et al. (2007) Bioconjugated quantum dots for multiplexed and quantitative immunohistochemistry. Nat Protoc 2(5): 1152-1165.

41. Suh KS, Park SW, Castro A, Patel H, Blake P, et al. (2010) Ovarian cancer biomarkers for molecular biosensors and translational medicine. Expert Rev Mol Diagn 10(8): 1069-1083.

42. Le Page C, Huntsman DG, Provencher DM, Mes-Masson AM (2010) Predictive and Prognostic Protein Biomarkers in Epithelial Ovarian Cancer: Recommendation for Future Studies. Cancers 2(2): 913-954.

43. Kretschmer C, Sterner-Kock A, Siedentopf F, Schoenegg W, Schlag PM, et al. (2011) Identification of early molecular markers for breast cancer. Mol Cancer 10(1): 15.

44. Cheng Q, Lau WM, Chew SH, Ho TH, Tay SK, et al. (2002) Identification of molecular markers for the early detection of human squamous cell carcinoma of the uterine cervix. Br J Cancer 86(2): 274-281.

45. Shappell SB (2008) Clinical utility of prostate carcinoma molecular diagnostic tests. Rev Urol 10(1): 44-69.

46. Bermudo R, Abia D, Mozos A, García-Cruz E, Alcaraz A, et al. (2011) Highly sensitive molecular diagnosis of prostate cancer using surplus material washed off from biopsy needles. Br J Cancer 105(10): 16001607.

47. Humphrey PA (2007) Diagnosis of adenocarcinoma in prostate needle biopsy tissue. J Clin Pathol 60(1): 35-42.

48. Hansel DE, DeMarzo AM, Platz EA, Jadallah S, Hicks J, et al. (2007) Early prostate cancer antigen expression in predicting presence of prostate cancer in men with histologically negative biopsies. J Urol 177(5): 1736-1740.

49. Smith RA, Brooks D, Cokkinides V, Saslow D, Brawley OW (2013) Cancer screening in the United States, 2013: A review of current american cancer society guidelines, current issues in cancer screening, and new guidance on cervical cancer screening and lung cancer screening. CA: Cancer J Clin 63(2): 87-105.

50. Zhong L, Coe SP, Stromberg AJ, Khattar NH, Jett JR, et al. (2006) Profiling 
tumor-associated antibodies for early detection of non-small cell lung cancer. J Thorac Oncol 1(6): 513-519.

51. Sequist LV, Yang JC, Yamamoto N, O’Byrne K, Hirsh V, et al. (2013) Phase III study of afatinib or cisplatin plus pemetrexed in patients with metastatic lung adenocarcinoma with EGFR mutations. J Clin Oncol 31(27): 3327-3334.

52. Jänne PA, Shaw AT, Pereira JR, Jeannin G, Vansteenkiste J, et al. (2013) Selumetinib plus docetaxel for KRAS-mutant advanced non-small-cell lung cancer: a randomised, multicentre, placebo-controlled, phase 2 study. Lancet Oncol 14(1): 38-47.

53. Gandhi L, Bahleda R, Tolaney SM, Kwak EL, Cleary JM, et al. (2014) Phase I study of neratinib in combination with temsirolimus in patients with human epidermal growth factor receptor 2-dependent and other solid tumors. J Clin Oncol 32(2): 68-75.

54. Reckamp KL, Giaccone G, Camidge DR, Gadgeel SM, Khuri FR, et al. (2014) A phase 2 trial of dacomitinib (PF-00299804), an oral, irreversible pan-HER (human epidermal growth factor receptor) inhibitor, in patients with advanced non-small cell lung cancer after failure of prior chemotherapy and erlotinib. Cancer 120(8): 11451154.

55. Chaft JE, Arcila ME, Paik PK, Lau C, Riely GJ, et al. (2012) Coexistence of PIK3CA and other oncogene mutations in lung adenocarcinomarationale for comprehensive mutation profiling. Mol Cancer Ther 11(2): 485-491.

56. Drilon A, Rekhtman N, Ladanyi M, Paik P (2012) Squamous-cell carcinomas of the lung: emerging biology, controversies, and the promise of targeted therapy. Lancet Oncol 13(10): e418-426.

57. Vaishnavi A, Capelletti M, Le AT, Kako S, Butaney M, et al. (2013) Oncogenic and drug-sensitive NTRK1 rearrangements in lung cancer. Nat Med 19(11): 1469-1472.

58. Tang J, Huang J, Su B, Chen H, Tang D (2011) Sandwich-type conductometric immunoassay of alpha-fetoprotein in human serum using carbon nanoparticles as labels. Biochem Eng J 53: 223-228.

59. Tang J, Huang J, Su B, Chen H, Tang D (2011a) Sandwich-type conductometric immunoassay of alpha-fetoprotein in human serum using carbon nanoparticles as labels. Biochem Eng J 53: 223-228.

60. Kim N, Kim DK, Cho YJ (2010) Gold nanoparticle-based signal augmentation of quartz crystal microbalance immunosensor measuring C-reactive protein. Curr Appl Physics 10: 1227-1230.

61. Wei Q, Mao K, Wu D, Dai Y, Yang J, et al. (2010a) A novel label-free electrochemical immunosensor based on graphene and thionine nanocomposite. Sensors Actuators B: Chem 149: 314-318.

62. Altintas Z, Fakanya WM, Tothill IE (2014b) Cardiovascular disease detection using bio-sensing techniques. Talanta 128: 177-186.

63. Chung J, Bernhardt R, Pyun J (2006) Additive assay of cancer marker CA 19-9 by SPR biosensor. Sens Actuators B Chem 118: 28-32.

64. Altintas Z, Kallempudi SS, Sezerman U, Gurbuz Y (2012) A novel magnetic particle-modified electrochemical sensor for immunosensor applications. Sens Actuators B Chem 174: 187-194.

65. Ladd J, Lu H, Taylor AD, Goodell V, Disis ML, et al. (2009) Direct detection of carcinoembryonic antigen autoantibodies in clinical human serum samples using a surface plasmon resonance sensor. Colloids Surf B Biointerfaces 70(1): 1-6.

66. Lee MH, Lee DH, Jung SW, Lee KN, Park YS, et al. (2010) Measurements of serum C-reactive protein levels in patients with gastric cancer and quantification using silicon nanowire arrays. Nanomed: Nanotechno Biol Med 6(1): 78-83.

67. Quershi A, Gurbuz Y, Kang W, Davidson JL (2009) A novel interdigitated capacitor based biosensor for detection of cardiovascular risk marker. Biosens Bioelectron 25(4): 877-882.
68. Kim N, Kim DK, Cho YJ (2010) Gold nanoparticle-based signal augmentation of quartz crystal microbalance immunosensor measuring C-reactive protein. Curr Appl Physics 10: 1227-1230.

69. Ilyas A, Asghar W, Allen PB, Duhon H, Ellington AD, et al. (2012) Electrical detection of cancer biomarker using aptamers with nanogap break-junctions. Nanotechnol 23(27): 275502.

70. Kallempudi SS, Altintas Z, Niazi JH, Gurbuz Y (2012) A new microfluid $\neg$ ics system with a hand-operated, on-chip actuator for immunosensor applications. Sens Actuators B Chem 163: 194-201.

71. Z, Niazi JH, Gurbuz Y (2012) A new microfluidics system with a handoperated, on-chip actuator for immunosensor applications. Sens Actuators B Chem 163: 194-201.

72. Sato Y, Fujimoto K, Kawaguchi H (2003) Detection of a K-ras point mutation employing peptide nucleic acid at the surface of a SPR biosensor. Colloids Surf B Biointerfaces 27: 23-31.

73. Qu B, Chu X, Shen G, Yu R (2008) A novel electrochemical immunosensor based on colabeled silica nanoparticles for determination of total prostate specific antigen in human serum. Talanta 76(4): 785-790.

74. Lin YY, Wang J, Liu G, Wu H, Wai CM, et al. (2008) A nanoparticle label/ immunochromatographic electrochemical biosensor for rapid and sensitive detection of prostate-specific antigen. Biosens Bioelectron 23(11): 1659-1665.

75. Prabhulkar S, Alwarappan S, Liu G, Li CZ (2009) Amperometric micro-immunosensor for the detection of tumor biomarker. Biosens Bioelectron 24(12): 3524-3530.

76. Kim PY, Lee BY, Lee J, Hong S, Sim SJ (2009b) Enhancement of sensitivity and specificity by surface modification of carbon nanotubes in diagnosis of prostate cancer based on carbon nanotube field effect transistors. Biosens Bioelectron 24(11): 3372-3378.

77. Yang X, Guo Y, Wang A (2010) Luminol/antibody labeled gold nanoparticles for chemiluminescence immunoassay of carcinoembryonic antigen. Analytica Chimica Acta 666(1-2): 91-96.

78. Triroj N, Jaroenapibal P, Shi H, Yeh JI, Beresford R (2011) Microfluidic chip-based nanoelectrode array as miniaturized biochemical sensing platform for prostatespecific antigen detection. Biosens Bioelectron 26(6): 2927-2933.

79. Wei Q Xiang Z, He J, Wang G, Li H, et al. (2010b) Dumbbell-like AuFe304 nanoparticles as label for the preparation of electrochemical immunosensors. Biosens Bioelectron 26(2): 627-631.

80. Li H, Wei Q, Wang G, Yang M, Qu F, et al. (2011) Sensitive electrochemical immunosensor for cancer biomarker with signal enhancement based on nitrodopamine-functionalized iron oxide nanoparticles. Biosens Bioelectron 26(6): 3044-3049.

81. Uludag Y, Tothill IE (2012) Cancer biomarker detection in serum samples using surface plasmon resonance and quartz crystal microbalance sensors with nanoparticle signal amplification. Anal Chem 84(14): 5898-5904.

82. Wang Y, Zhu X, Wu M, Xia N, Wang J, et al. (2009) Simultaneous and label-free determination of wild-type and mutant p53 at a single surface plasmon resonance chip preimmobilized with consensus DNA and monoclonal antibody. Anal Chem 81(20): 8441-8446.

83. Altintas Z, Tothill IE (2012) DNA-based biosensor platforms for the detection of TP53 mutation. Sens Actuators B Chem 169: 188-194.

84. Tang Z, Liu P, Ma C, Yang X, Wang K, et al. (2011b) Molecular beacon based bioassay for highly sensitive and selective detection of nicotinamide adenine dinucleotide and the activity of alanine aminotransferase. Anal Chem 83(7): 2505-2510.

85. Xu H, Hepel M (2011) Molecular beacon"-based fluorescent assay for selective detection of glutathione and cysteine. Anal Chem 83(3): 813819. 
86. Piao Y, Liu F, Seo TS (2012) A novel molecular beacon bearing a graphite nanoparticle as a nanoquencher for in situ mRNA detection in cancer cells. ACS Appl Mater Interfaces 4(12): 6785-6789.

87. Miao X, Guo X, Xiao Z, Ling L (2014) Electrochemical molecular beacon biosensor for sequence-specific recognition of double-stranded DNA. Biosens Bioelectron 59: 54-57.

88. Mittal S, Kaur H, Gautam N, Mantha AK (2017) Biosensors for breast cancer diagnosis: A review of bioreceptors, biotransducers and signal amplification strategies. Biosens Bioelectron 88: 217-231.

89. Karimi-Busheri F, Rasouli-Nia A, Zadorozhny V, Fakhrai H (2013) CD24+/ CD38- as new prognostic marker for non-small cell lung cancer. Multidiscip Respir Med 8(1): 65.

90. Esteva FJ, Hortobagyi GN (2004) Prognostic molecular markers in early breast cancer. Breast Cancer Res 6(3): 109-118.

91. Cruz I, Ciudad J, Cruz JJ, Ramos M, Gómez-Alonso A, et al. (2005)
Evaluation of multiparameter flow cytometry for the detection of breast cancer tumor cells in blood samples. Am J Clin Pathol 123(1): 66-74.

92. Miller GJ, Brawer MK, Sakr WA, Thrasher JB, Townsend R (2001) Prostate cancer: serum and tissue markers. Rev Urol 3(2): S11-19.

93. Hessels D, Verhaegh GW, Schalken JA, Witjes JA. (2004) Applicability of biomarkers in the early diagnosis of prostate cancer. Expert Rev Mol Diagn 4(4): 513-526.

94. Bast RC, Brewer M, Zou C, Hernandez MA, Daley M, et al. (2007) Prevention and early detection of ovarian cancer: mission impossible? Recent Results Cancer Res 174: 91-100.

95. El-Sahwi KS, Schwartz PE, Santin AD (2012) Development of targeted therapy in uterine serous carcinoma, a biologically aggressive variant of endometrial cancer. Expert Rev Anticancer Ther 12(1): 41-49.

Your next submission with Juniper Publishers will reach you the below assets

- Quality Editorial service

- Swift Peer Review

- Reprints availability

- E-prints Service

- Manuscript Podcast for convenient understanding

- Global attainment for your research

- Manuscript accessibility in different formats

( Pdf, E-pub, Full Text, Audio)

- Unceasing customer service

Track the below URL for one-step submission https://juniperpublishers.com/online-submission.php 